\title{
Seasonal changes in depth distribution, sex ratio and size frequency of spiny lobster Jasus edwardsii on a coastal reef in northern New Zealand
}

\author{
A. B. MacDiarmid* \\ Leigh Marine Laboratory and Department of Zoology, University of Auckland, Auckland, New Zealand
}

\begin{abstract}
Patterns of abundance and movement of the spiny lobster Jasus edwardsii (Hutton) (F. Palinuridae) were examined within a coastal reef system. Overall population size remained relatively stable over a 3 yr study period. Marked differences in density, sex ratio and size frequency of spiny lobsters occurred between depths on the reef over a horizontal scale of $300 \mathrm{~m}$. These differences varied seasonally and were related to moulting, reproductive and feeding cycles. They were not directly linked to fluctuations in sea surface temperature, sea surge or photoperiod. Similar annual trends occurred at other sites. Highest densities of females in shallow $(<10 \mathrm{~m})$ water coincided with moulting in May. Males moved inshore only briefly to moult in October-November often with no concomitant increase in male density in shallow $(<10 \mathrm{~m})$ water. Increases in density of females at the deep $(25 \mathrm{~m})$ seaward edge of the coastal reef occurred during the egg-bearing period. In summer (December, January) the density of large males at a deep patch reef $(25$ to $30 \mathrm{~m}$ ) increased. These males foraged nocturnally for bivalves on the surrounding sand flat. Resighting of tagged individuals confirmed that the observed fluctuations in density, sex ratio and size frequency of spiny lobsters at different depths were caused by males and females moving inshore-offshore at different times of the year
\end{abstract}

\section{INTRODUCTION}

There is some evidence for marked seasonal changes in the depth distribution of the spiny lobster Jasus edwardsii (Hutton) (F. Palinuridae) in New Zealand. Street (1969) found large numbers of female lobsters inshore on heavily creviced substrate during moulting. McKoy \& Leachman (1982) found dense aggregations of ovigerous females at the deep seaward edge of coastal reefs. In other palinurid species variations in the abundance of particular sizes and sex among depth, season and site have been reported (Kanciruk \& Herrnkind 1973, Mercer 1975, Davis 1977, Pollock 1979, Herrnkind 1980, Kanciruk 1980, Lyons et al. 1981, Pollock 1982).

These fluctuations may reflect actual changes in lobster population size and structure or merely be sampling artifacts (Phillips 1990). Distributional data

- Present address: Fisheries Research Centre, Greta Point, PO Box 297, Wellington, New Zealand obtained by sampling the commercial catch are usually broad in scale (Ford 1980) and difficult to interpret because of seasonal, size and sex specific changes in catchability (Morgan 1974a, b) which mask underlying variability in lobster population size and structure. Tagrecapture programmes have been used in attempts to gain a clearer picture of the size and distribution of some lobster populations (Morgan 1974a, Peacock 1974, Ford et al. 1988). Basic assumptions of these methods are often not met (Phillips 1990) and if captures rely exclusively on trapping, then the problems of trap bias apply (Morgan 1974a, b, Kanciruk \& Herrnkind 1976, Ford 1980). Moreover, the smallest distributional scales resolvable are determined by the area the trap fishes and the period that it is set (Brethes et al. 1985). Jernakoff \& Phillips (1988) found the spiny lobster Panulirus cygnus to travel as far as $120 \mathrm{~m}$ upcurrent to a baited trap. Obviously trapping cannot resolve differences in density on a scale less than this distance.

In other studies lobsters have been hand-collected to determine abundance, sex ratio and size distribution 
(e.g. Heydorn 1969, Pollock 1973, Morgan 1974a, Newman \& Pollock 1974, Berry \& Smale 1980, Breen \& Booth 1989, Davis \& Dodrill 1989). While avoiding the problems associated with trapping this method is labour intensive and can bias estimates of size frequency because lobsters of different sizes vary in ease of capture (Pollock 1973, Breen \& Booth 1989). In addition, hand capture may affect population size and structure by increasing emigration from the sample area (Herrnkind et al. 1975, Davis 1977, Jernakoff et al 1987, MacDiarmid et al. in press). This may be the prime reason Berry \& Smale (1980) found the numbers of Panulirus homarus on a small study reef to decrease by $70 \%$ after 3 yr of quarterly hand sampling, measuring, then liberating, every lobster over $20 \mathrm{~mm}$ CL.

In this study the static and dynamic patterns of distribution of Jasus edwardsii on a coastal reef in northeastern New Zealand are described. The aim was 2-fold. First, to monitor for 3 yr the overall size and structure of a protected population, and second, to examine seasonal changes in depth distribution in relation to annual cycles in moulting, reproduction, feeding, sea temperature, photoperiod and wave height. By studying a protected population it was possible to investigate fluctuations in distribution, abundance and structure, free from any confounding effects of the fishery.

I employed a visual census technique, similar to those used in studying reef fishes (McCormick \& Choat 1987), in combination with tagging studies. In a visual census, replicated, randomly positioned, transects are searched for target species. The method shares with hand collection the advantage of yielding direct counts of lobsters but is more rapid, not biased towards particular sizes, and non-destructive enabling repeated counts to be made. Lobsters are particularly suited to this technique because they are large, sedentary animals which can be approached closely enough to determine sex and estimate size (Davis 1977, Smith \& van Nierop 1986). Increasingly, visual census methods are used to estimate lobster abundance (Schmitt 1982, Ennis 1984, Smith \& van Nierop 1986, Barkai \& Branch 1988, Ford et al. 1988, Karnofsky et al. 1989). In these studies, as in many ecological investigations, the size of the transect or quadrat to be used and the number of replicates to be sampled have been arbitrarily chosen, without adequate testing of their precision (Pringle 1984, Andrew \& Mapstone 1987). As no previous studies have estimated the abundance of Jasus edwardsii using visual count methods I determined the appropriate sample unit and number of replicates.

The only unequivocal method of confirming patterns of movement suspected because of changes in density, sex ratio or size distribution is to track tagged animals (Herrnkind 1980). I adopted this approach to describe seasonal inshore and offshore movements of Jasus edwardsii. To avoid problems associated with trapping, lobsters were hand-captured for tagging and resighted in situ.

\section{MATERIALS AND METHODS}

Study area. I chose a population of Jasus edwardsii in the Cape Rodney to Okakari Point Marine Reserve $\left(174^{\circ} 46^{\prime} \mathrm{E}\right.$ to $174^{\circ} 49^{\prime} \mathrm{E}, 36^{\circ} 16^{\prime} \mathrm{S}$; hereafter referred to as the Marine Reserve) for study. This population has been free from commercial and recreational exploitation since 1977 (Ballantine 1987). Within the Marine Reserve a $5 \mathrm{~km}$ continuous coastal reef extends to $400 \mathrm{~m}$ from the shore line and reaches a depth of 20 to $25 \mathrm{~m}$. The shore is exposed to ocean waves from the north and east. Tabletop Reef within the Marine Reserve was the main focus of investigation (Fig. 1). It was divided into an inner or shallow Site $1(0$ to $10 \mathrm{~m})$, a mid Site $2(>10$ to $17 \mathrm{~m}$ ) and an outer or deep Site 3 ( $>17$ to $25 \mathrm{~m}$ ). Each site covered an area of ca $6700 \mathrm{~m}^{2}$. Other sites in the Marine Reserve were surveyed on various occasions as described below. Their locations are inset in Fig. 1.

General survey methods. Information on spiny lobsters was obtained in visual surveys using SCUBA. Carapace length (CL), defined as the distance from the base of the antennal platform to the dorsal, posterior margin of the carapace along the mid-line, was estimated by eye to the nearest $5 \mathrm{~mm}$. To assess the error associated with this technique I first estimated the carapace length of 80 individuals and then measured it after capture. Average difference between estimated and measured size was $\pm 5 \mathrm{~mm}$ CL for lobsters ranging in size from 20 to $185 \mathrm{~mm}$ CL. Measurement error, estimated by taking 5 repeated measures of the carapace length of 10 females, was 0.04 to $1.41 \%$ of the means.

To estimate densities, transects were positioned either using a fibreglass tape as a base line and running out a second tape at a predetermined random distance or by random choice of numbered grids (chosen using a table of random numbers) marked out on a map of the survey area carried by the diver. The entire transect (see following section for transect dimensions) was thoroughly searched and the estimate of carapace length and sex of every spiny lobster observed was recorded. Individuals were sexed by shining a narrow flash-light beam onto sexually dimorphic characters such as the 5th periopod, the pleopods and the genital opening (see Patterson 1968). No lobster was ever captured or handled using this method. Lobsters typically sat near the entrance to their wedge-shaped shelter, enabling thorough searching. Shelters which could not be easily searched were rare. 


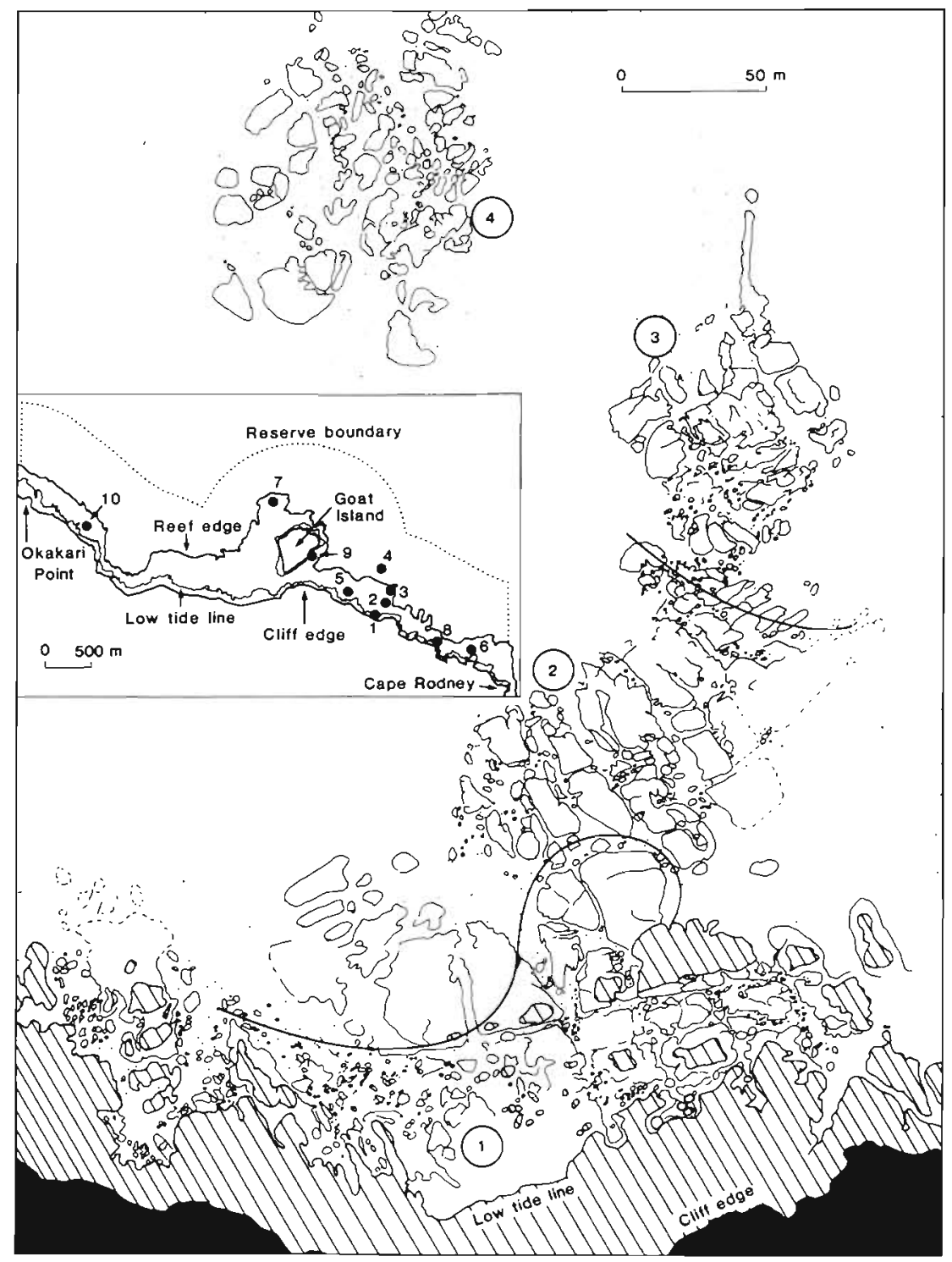

Fig. 1. Tabletop Reef showing its divisions into Inner Tabletop (Site 1), Mid Tabletop (Site 2) and Outer Tabletop (Site 3). Site 4 (Deep Patch Reefs) is also shown. Inset is a map of the Marine Reserve showing the location of study sites

Transect size and number of replicates. I determined the size and number of replicate transects required to yield reliable estimates of population density of spiny lobsters. The position of every spiny lobster at Inner and Outer Tabletop Reef was recorded on scale maps on 2 occasions (March 1985 and May 1985 for Inner Tabletop; September 1984 and March 1985 for Outer Tabletop). These times were chosen because they were periods of high and low density for each locality. On each occasion lobster positions were recorded in $1 \mathrm{~d}$ at Inner Tabletop but over $3 \mathrm{~d}$ at Outer Tabletop because of dive time limitations imposed by depth. This longer period at Outer Tabletop did not affect the pattern of distribution as spiny lobsters move randomly throughout an area during night and often return to their original shelter (MacDiarmid et al. in press).

The maps of spiny lobster distributions were later used to generate estimates of the variance associated with strip transects of 3 sizes, $10 \times 10 \mathrm{~m}, 25 \times 10 \mathrm{~m}$ and $50 \times 10 \mathrm{~m}$. Thirty replicate transects of each size were placed at random points and random orientations on each map. Spiny lobsters within each transect were counted. To overcome the problem of transects which ran off the edge of map, replicate copies of each map were placed around the original (as in McCormick \& Choat 1987). A density estimate and standard deviation was produced for each transect size on each map. The precision $\left[p=(\mathrm{s} / \vee \mathrm{n}) / \bar{x}_{\text {; }}\right.$ where $\mathrm{s}=$ sample standard deviation, $\mathrm{n}=$ number of replicates, $\overline{\mathrm{x}}=$ mean density] of each transect size on each sampling occasion was calculated when $2000 \mathrm{~m}^{2}$ was censused. Thus $\mathrm{n}=20,8$ and 4 for the smallest to largest transect respectively. Mean precision and $95 \%$ confidence limits were calculated for each transect size. 

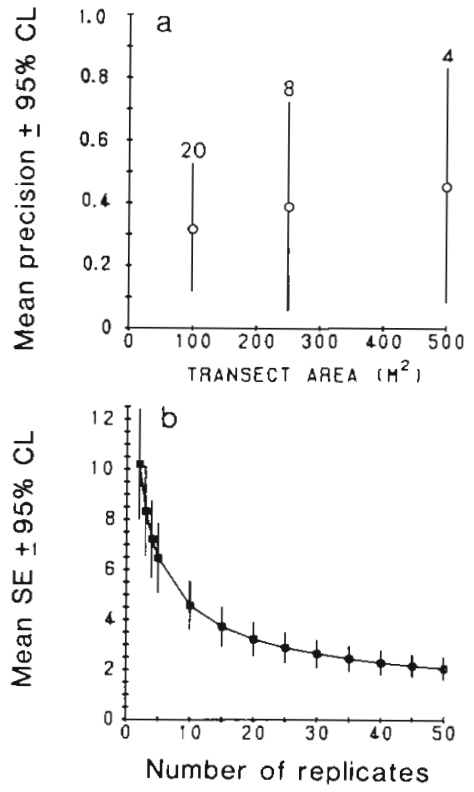

Fig. 2. (a) Comparison of the precision of density estimates from 3 transect sizes $\left(100,250\right.$ and $\left.500 \mathrm{~m}^{2}\right)$ when $2000 \mathrm{~m}^{2}$ were sampled. The number of transects required to sample this area is shown. (b) Precision of density estimates generated when varying numbers of replicate $10 \times 10 \mathrm{~m}$ transects were used to sample a mapped population of Jasus edwardsii

The precision of the 3 different sized transects when $2000 \mathrm{~m}^{2}$ were sampled, plotted as the mean $\pm 95 \% \mathrm{CL}$ of the 4 sample occasions, is shown in Fig. 2a. All transect sizes produced estimates of similar precision although the $10 \times 10 \mathrm{~m}$ transect was the most precise and least variable between times and places as indicated by the smaller $95 \%$ confidence limits. This transect size had other advantages. To sample an equal area of reef the $10 \times 10 \mathrm{~m}$ transect required 2.5 times as many replicates as the $25 \times 10 \mathrm{~m}$ transect and 5 times as many replicates as the $50 \times 10 \mathrm{~m}$ transect. Large sample numbers make most statistical analyses robust to violations of assumptions (Green 1979). In addition, the $10 \times 10 \mathrm{~m}$ transect was easier to search in the field than the larger transects and was more suited to the scale of the areas sampled. The $10 \times 10 \mathrm{~m}$ transect reached a relatively stable level of precision when 20 replicates were sampled (Fig. 2b), and was chosen as the main sampling unit after 1983. However, as described below, different sizes of transects and numbers of replicates were used in some parts of this study and are described in the relevant sections.

Seasonal changes in depth distribution. Densities of spiny lobsters were estimated at the 3 sites on Tabletop Reef at intervals of 1 to 2 mo, from September 1982 to September 1985. Three additional sites, one at each depth, were examined on other reefs in the Marine Reserve during 1982 and 1983. These sites were Site 5
(0 to $10 \mathrm{~m})$, Site $6(10$ to $17 \mathrm{~m}$ ) and Site 7 (17 to $25 \mathrm{~m}$ ) (Fig. 1). During 1982 and 1983 densities at each site were estimated using $50 \times 10 \mathrm{~m}$ transects ( $\times 5$ replicates). Data in each $10 \mathrm{~m}$ segment was recorded separately. In 1984 and 1985 densities were estimated using $10 \times 10 \mathrm{~m}$ quadrats $(\times 20$ replicates per site). Transects and quadrats were searched as described above. The 1982/83 and 1984/85 Tabletop Reef data sets were analysed in separate 2-factor Analyses of Variance (ANOVA). In both analyses factors were Month (September 1982 to December 1983 and April 1984 to September 1985 respectively) and Gender. Depth was not incorporated into the analyses because lobsters were moving between depths making them non-independent. For graphical display all densities are presented as numbers per $100 \mathrm{~m}^{2}$. The 5 replicate $50 \times 10 \mathrm{~m}$ transects collected at each site/time combination in $1982 / 83$ were equivalent to 25 quadrats of $10 \times 10 \mathrm{~m}$ in terms of area searched. To make these equivalent to the 1984/85 data, 5 quadrats of the 1982/83 data were dropped at random and the means etc. calculated for the remaining 20 quadrats.

At Deep Patch Reefs (Site 4, Fig. 1), 100 m northwest of Tabletop Reef, densities were estimated 6 times from December 1984 to September 1985. Because the depth of this site $(25 \mathrm{~m})$ imposed bottomtime restrictions during diving, and high densities were encountered, spiny lobsters were counted in 20 randomly placed $5 \times$ $5 \mathrm{~m}$ quadrats.

The survey data were used to describe changes in the sex ratio and size distribution of spiny lobsters at each site as well as to describe changes in abundance. Additional data on variations in size structure among sites at the same depth and at the same time were examined by surveying 5 shallow ( 0 to $10 \mathrm{~m}$ ) sites $(1,5$, 8, 9 and 10; see inset Fig. 1) in March/April 1985. Lobsters were counted, sized and sexed in 15 randomly placed $10 \times 10 \mathrm{~m}$ quadrats at each site as described above.

Inshore-ofishore movements of tagged lobsters. Spiny lobsters were tagged underwater using SCUBA. Individuals were captured by hand during the day. One diver held the lobster while the other measured its carapace length (CL), determined its sex and attached a numbered western rock-lobster tag (Chittleborough 1974) composed of a plastic anchor and spaghetti tubing. Because these tags were difficult to read underwater without disturbing the lobster, 2 temporary antennae tags, clearly visible a metre or more from the lobster, were also attached. Antennae tags were made of plastic electrical cable ties, $200 \mathrm{~mm}$ long and $4 \mathrm{~mm}$ wide, onto which were threaded a maximum of 3 short segments (4 mm long) of coloured $4 \mathrm{~mm}$ diameter plastic tube. Six colours were utilised resulting in 23000 unique combinations which could be read from 
either direction. At the time of tagging it was noted which shelter site the spiny lobster came from, and whether the lobster was pre- or post-moult (during moulting periods only), was carrying eggs (females only) and had lost appendages. Pre- and post-moult lobsters were distinguished by the presence or absence of fouling organisms on the exoskeleton. Most individuals tagged were mature (MacDiarmid 1989a) and moult once per year (MacDiarmid 1989b). After tagging the lobster was returned to its shelter site. The whole operation took 6 min on average. To minimise disturbance usually one lobster per shelter was tagged on any one day.

A total of 433 spiny lobsters was tagged on Tabletop Reef between 1982 and 1985. Resighting of these individuals established the seasonal timing of inshore/offshore movements of male and female spiny lobsters. An inshore or offshore movement was defined as a change of sites, e.g. Inner Tabletop to Mid or Outer Tabletop. Lobsters that were resighted too infrequently to determine the season of movement were excluded.

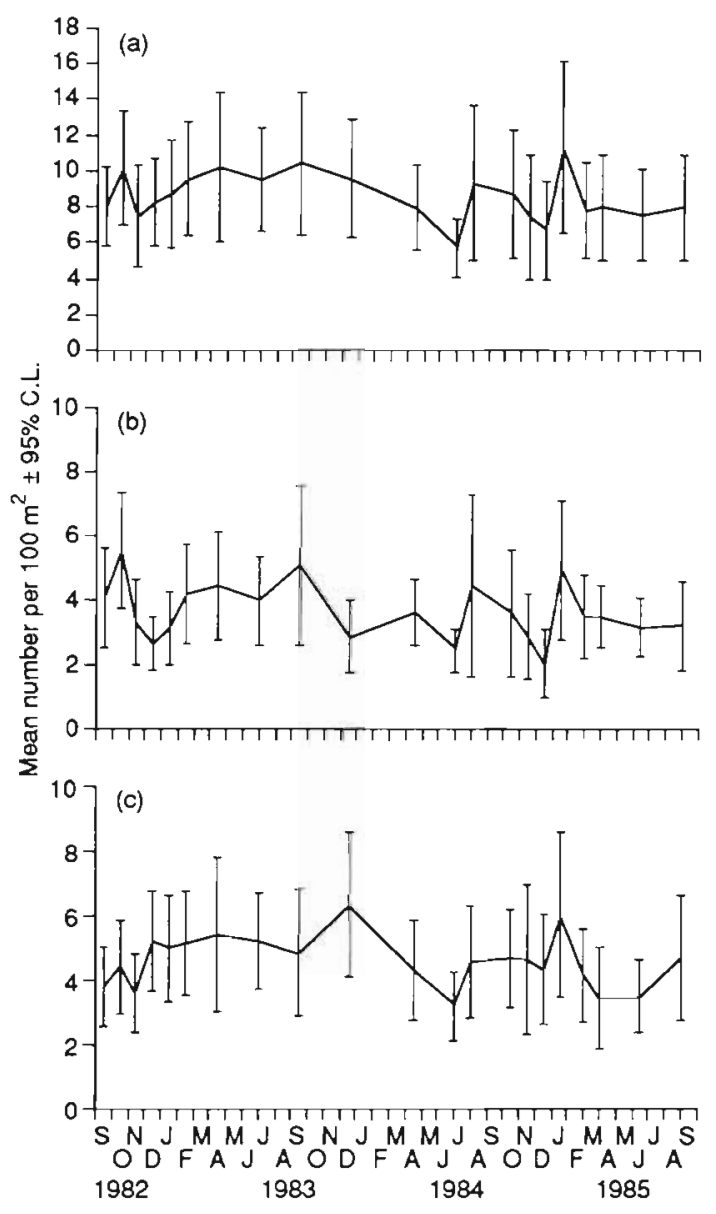

Fig. 3. Jasus edwardsii. Density (mean $100 \mathrm{~m}^{-2} \pm 95 \%$ confidence limits) on Tabletop Reef (Sites 1,2, and 3 combined).

(a) Total, (b) males, (c) females
Table 1. Jasus edwardsii. Effects of month and gender on densities on Tabletop Reef in 1982/83 and 1984/85. Analysis is by 2 -factor ANOVA. Both factors fixed. Data were $V(x+0.5)$ transformed. The Shapiro-Wilk statistic for normality of transformed data is $W=0.968, \mathrm{p}<0.001$ for $1982 / 83$ and $W=$ $0.819, \mathrm{p}<0.001$ for $1984 / 85$

\begin{tabular}{|lrrrrc|}
\hline Source & \multicolumn{1}{c}{ SS } & df & MS & $F$ & $\mathrm{p}$ \\
\hline 1982/83 & & & & & \\
Month & 9.4748 & 9 & 1.0528 & 0.35 & NS \\
Gender & 13.0534 & 1 & 13.0534 & $4.35<0.05$ \\
Month $\times$ Gender & 26.2429 & 9 & 2.9159 & 0.97 & NS \\
Residual & 839.6296 & 280 & 2.9987 & & \\
1984/85 & & & & & \\
Month & 16.0512 & 10 & 1.6051 & 1.18 & NS \\
Gender & 8.4513 & 1 & 8.4513 & $6.23<0.05$ \\
Month $\times$ Gender & 10.1866 & 10 & 1.0187 & 0.75 & NS \\
Residual & 1760.4202 & 1298 & 1.3563 & & \\
\hline
\end{tabular}

The effort expended in each site to resight tagged lobsters was recorded as this can influence the apparent net direction of movement by the tagged population (Campbell \& Stasko 1985).

\section{RESULTS}

\section{Seasonal change in depth distribution}

\section{Densities}

Overall densities of spiny lobsters on Tabletop Reef (Sites $1,2 \& 3$ combined) varied little during the 3 yr of this study averaging $8.6 \pm 0.3$ (SE) $100 \mathrm{~m}^{-2}$ (Fig. 3a). Analyses of variance of the 1982/83 and 1984/85 data found significant differences in abundances of males and females on Tabletop Reef (Table 1). Overall, males were about $20 \%$ less abundant than females (Fig. 3b, c). There were no significant effects of Month or Month $\times$ Gender interaction in either analysis. Mean densities of lobsters on Tabletop Reef during the 3 yr study were highest at Outer Tabletop [10.01 \pm 1.41 (95\% CL) 100 $\left.\mathrm{m}^{-2}\right]$ and lowest at Mid Tabletop [7.07 \pm 1.16 (95\% CL) $100 \mathrm{~m}^{-2}$ ].

These differences were not static. When males and females at different depths were considered separately, considerable variation in densities occurred between months. Females exhibited the clearest pattern (Fig. 4). In shallow areas (Fig. 4a) highest densities of females occurred in April/May and lowest densities in August/ September. In deep areas (Fig. 4c) the pattern was reversed, with highest densities occurring in August/ September and lowest densities in April/May. This inverse relationship is more clearly illustrated in Fig. 5 in which densities of females at Outer Tabletop are 
plotted against female densities at Inner Tabletop. A significant negative relationship was found $(\mathrm{r}=-0.63$, $\mathrm{df}=19, \mathrm{p}<0.005)$. Densities of females at mid depths (Fig. 4b) were usually lower and fluctuated less than those at shallow and deep reefs. Sometimes, however, they reflected patterns occurring in either deep or shallow areas but this was not consistent between years. Densities of females at the other shallow site

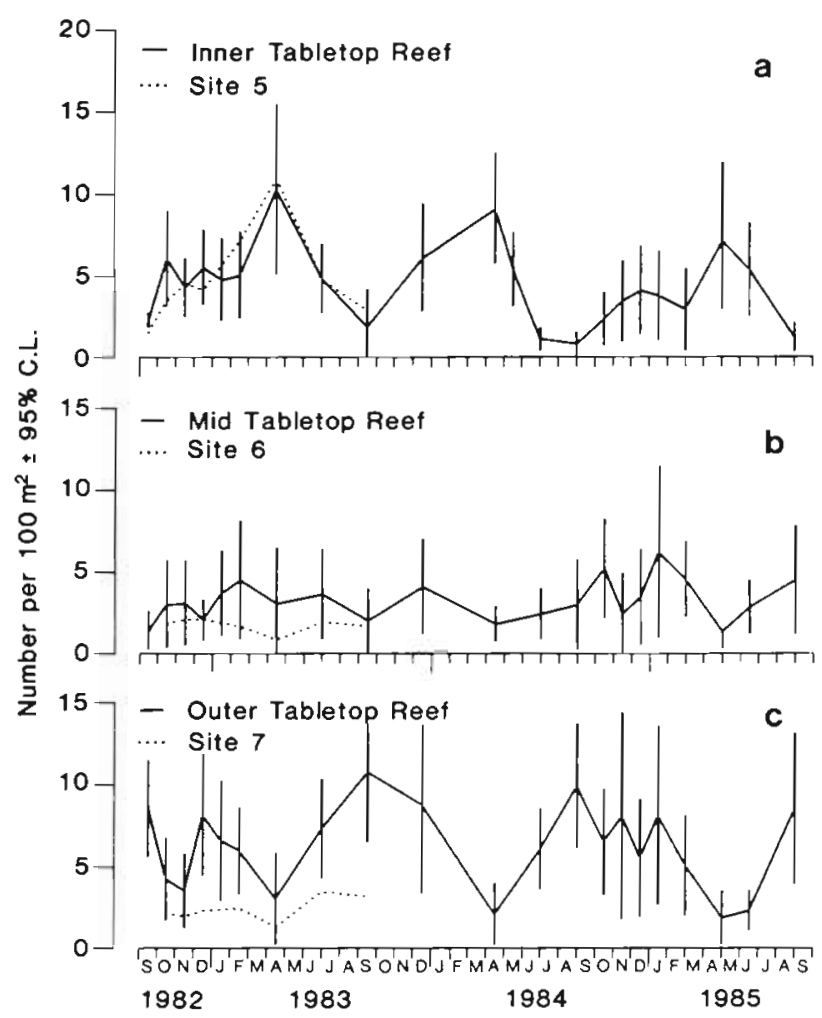

Fig. 4. Jasus edwardsii. Density (mean $100 \mathrm{~m}^{-2} \pm 95 \%$ confidence limits) of females at (a) Inner Tabletop, (b) Mid Tabletop and (c) Outer Tabletop 1982 to 1985. Mean density of females at the additional site at each depth sampled in 1982/ 83 is shown as a dashed line

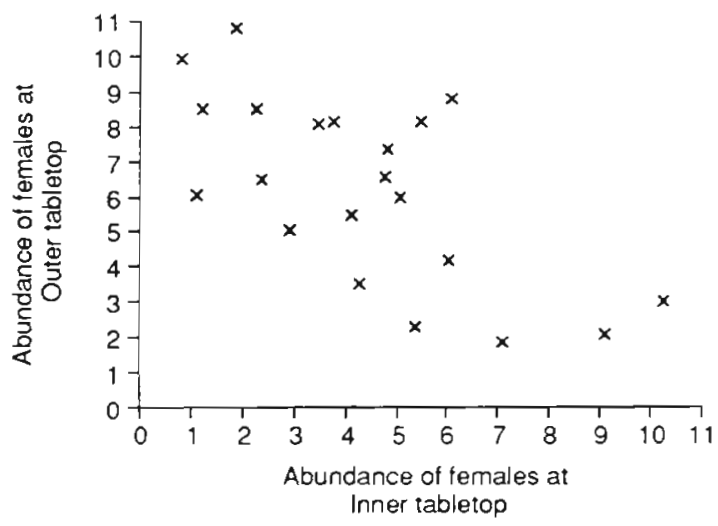

Fig. 5. Jasus edwardsij. Mean abundance $\left(100 \mathrm{~m}^{-2}\right)$ of females at Outer Tabletop plotted against the mean abundance of females at Inner Tabletop for each sampling date September 1982 to August/September 1985 sampled in 1982/83 showed the same fluctuations as Inner Tabletop (Fig. 4a). At the additional mid and deep sites sampled in 1982/83 females were not as abundant and did not show the same fluctuations as found at equivalent depths on Tabletop Reef.

Changes in abundance of males were small and often irregular. Variation in density among transects within sites tended to obscure temporal variation. The most regular changes in abundance occurred at Mid Tabletop where the highest densities in each year were found in September or October (Fig. 6b) in depths of 10 to $13 \mathrm{~m}$. Densities reached their lowest levels in December of each year. Densities of males at Site 5 , the additional shallow site sampled in 1982 and 1983, also peaked in September/October but at Inner Tabletop high densities were found only in September/October 1982 (Fig. 6a). The abundance of males at Outer Tabletop fluctuated little (Fig. 6c). The highest densities of males on the deep patch reefs (Site 4) $100 \mathrm{~m}$ to the northwest of Tabletop Reef were found in December 1984 (Fig, 7). Subsequent observations in December 1985 and 1986 confirmed the presence of high densities at this site.

\section{Sex ratios}

Large cyclical changes in sex ratio were found at both Inner and Outer Tabletop but were out of phase (Fig. 8a, c). For example in April/May, when fermales dominated at Inner Tabletop, the percentage females at Outer Tabletop was low. The sex ratio at Mid Tabletop (Fig. 8b) was irregular. Sex ratios at sites at the same depth but up to $2 \mathrm{~km}$ apart were very similar at the same time of year (additional sites shown as dotted lines in Fig. 8a, b, c). Overall sex ratios on Tabletop Reef (Sites 1, 2 and 3 combined) (Fig. 8d) were biased towards females $\left(56 \%, \chi^{2}=47.8, \mathrm{n}=3465\right)$ particularly in December of each year when they comprised almost $70 \%$ of the population. However, in September/ October and the period March to May, ratios approached or equalled $50 \%$

\section{Size distributions}

Spiny lobsters on Tabletop Reef ranged in size from small recently settled post-larvae of $15 \mathrm{~mm}$ CL to large adult males of $200 \mathrm{~mm}$ CL (Fig. 9). The population was composed predominantly of adults $>85 \mathrm{~mm}$ CL. Females formed a large mode between 110 and $130 \mathrm{~mm}$ $\mathrm{CL}$ with few larger than $150 \mathrm{~mm} \mathrm{CL}$. Adult males ranged more widely in size with peak modes between 150 and $180 \mathrm{~mm} \mathrm{CL}$.

Differences in size frequency of spiny lobsters among 
sites at the same depth were minor compared with annual changes at any one site or differences among depths at one time. For example, contrast the relatively small differences in size frequency among 5 shallow

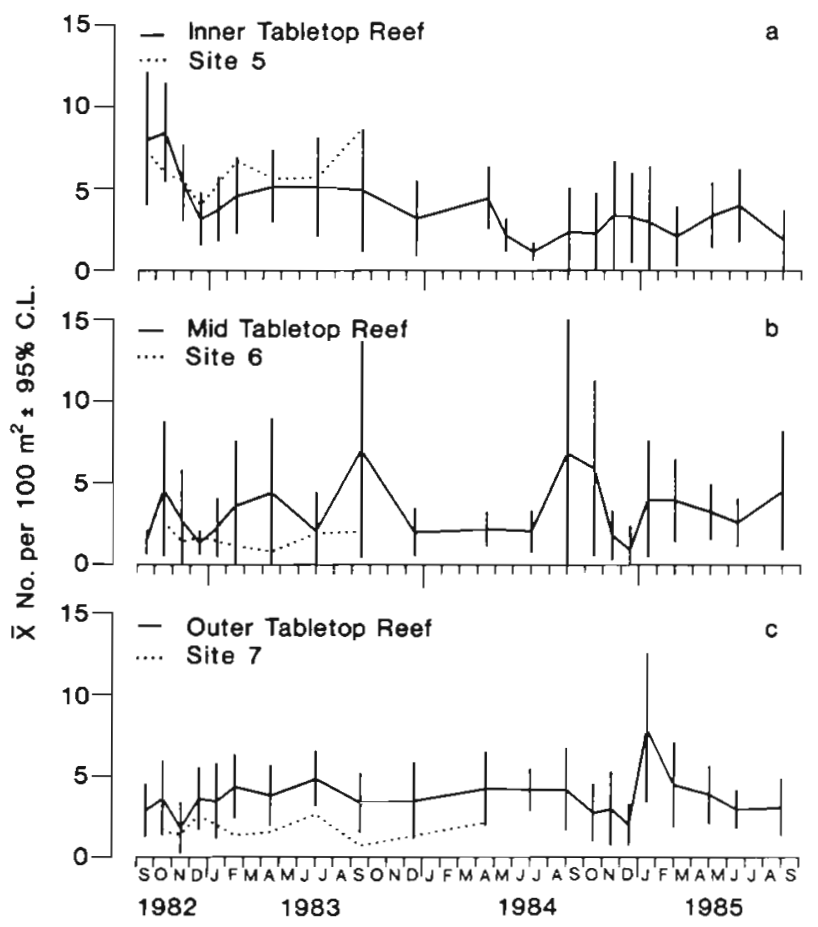

Fig. 6. Jasus edwardsii. Density (mean $100 \mathrm{~m}^{-2} \pm 95 \%$ confidence limits) of males at (a) Inner Tabletop, (b) Mid Tabletop and (c) Outer Tabletop 1982 to 1985. Mean density of males at the additional site at each depth sampled in 1982/83 is shown as a dashed line

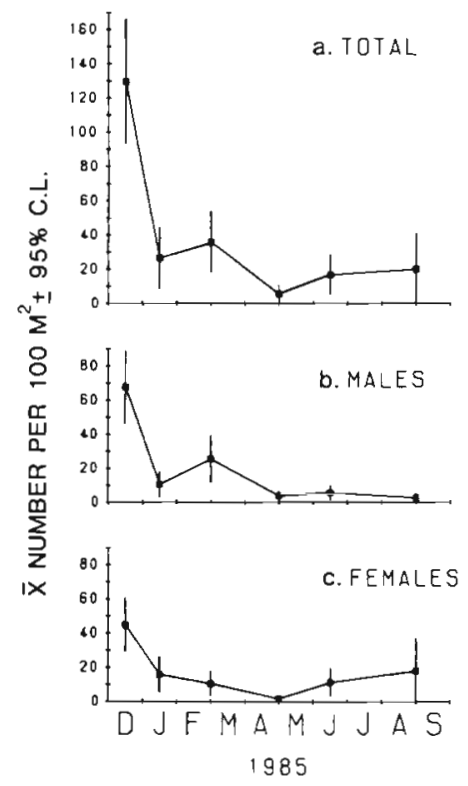

Fig. 7. Jasus edwardsii. Density (mean $100 \mathrm{~m}^{-2} \pm 95 \%$ confidence limits) at Site 4. (a) Total rock lobsters, (b) males, (c) females

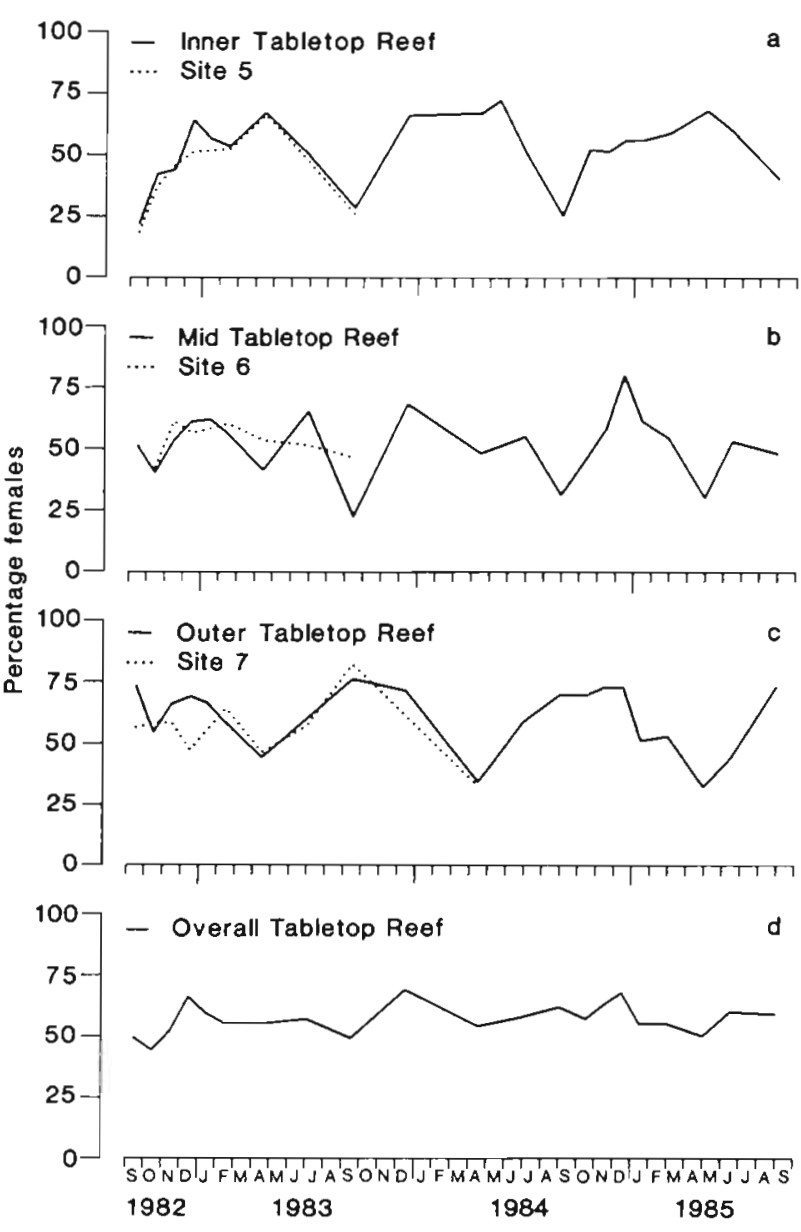

Fig. 8. Jasus edwardsii. Sex ratio (\% females) at (a) Inner Tabletop, (b) Mid Tabletop, (c) Outer Tabletop, (d) Overall Tabletop Reef. Sex ratios at the additional site sampled at each depth in 1982/83 are shown as dashed lines

sites, surveyed in March/April 1985 (Fig. 10) with the annual, cyclical changes observed at Inner Tabletop (Fig. 11). The main feature at Inner Tabletop in April 1984 was the strong female mode between 110 and $130 \mathrm{~mm}$ CL. This disappeared by August and did not fully reappear till April/May 1985. This cycle was repeated every $12 \mathrm{mo}$, producing similar size distributions at the same site, in the same month, each year (e.g. Fig. 12).

Marked differences in the size distribution of spiny lobsters were observed at different depths, at particular times of the year. For example, on Tabletop Reef differences were greatest between shallow and deep sites, and were most extreme in April and again in September of each year when the size distributions at these 2 depths were opposite (Fig. 13a, c, d, f). In comparison, the size distribution of spiny lobsters at Mid Tabletop changed relatively little between April and September 1983. The major difference was an increase in the number of males larger than $125 \mathrm{~mm} \mathrm{CL}$ in September. 
Except for the low numbers of juveniles at the deep site, size distributions were similar at all depths on Tabletop Reef in November 1982 (Fig. 12g, h, i). This was typical of late spring and summer distributions for every year sampled.

Juveniles $<85 \mathrm{~mm} \mathrm{CL}$ were always more abundant in shallow areas than deep areas. Of the 1521 spiny lobsters of this size counted during routine surveys, $55 \%, 33 \%$ and $12 \%$ were found at the shallow, mid and deep sites respectively.

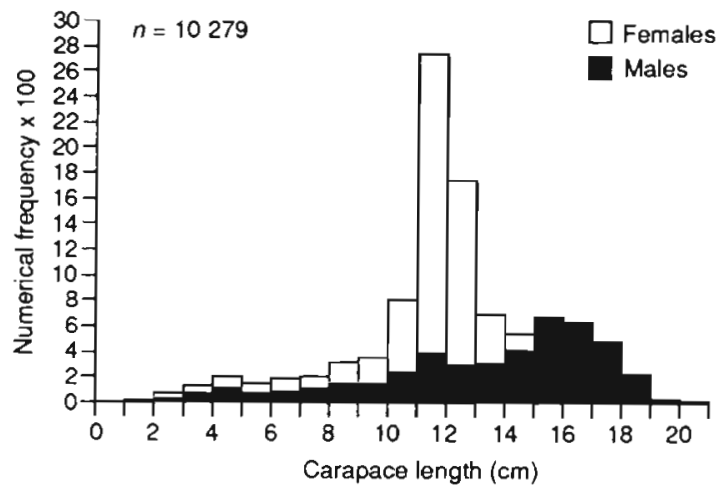

Fig. 9. Jasus edwardsii. Pooled size frequency distribution on Tabletop Reef (Sites 1, 2 \& 3) over the 3 yr study. Proportion of each size class comprised by males is shown in black

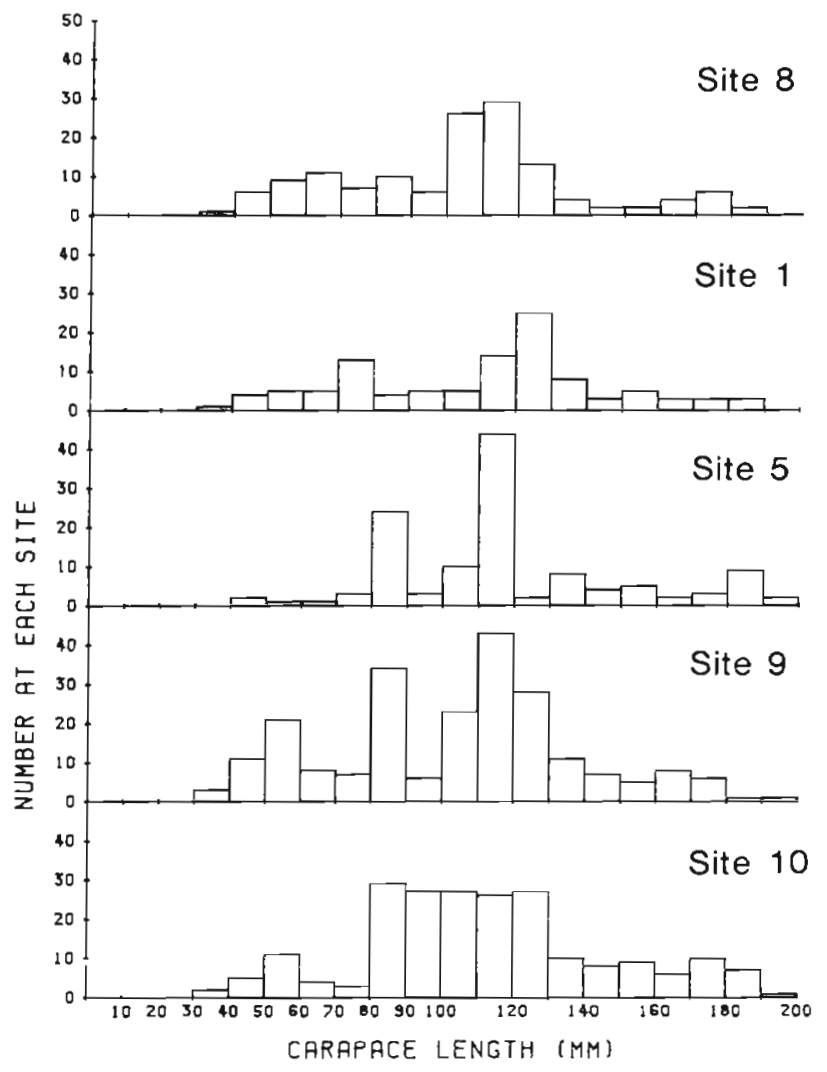

Fig. 10. Jasus edwardsii. Comparison of size frequencies among 5 shallow broken rock sites in the Marine Reserve in March/April 1985

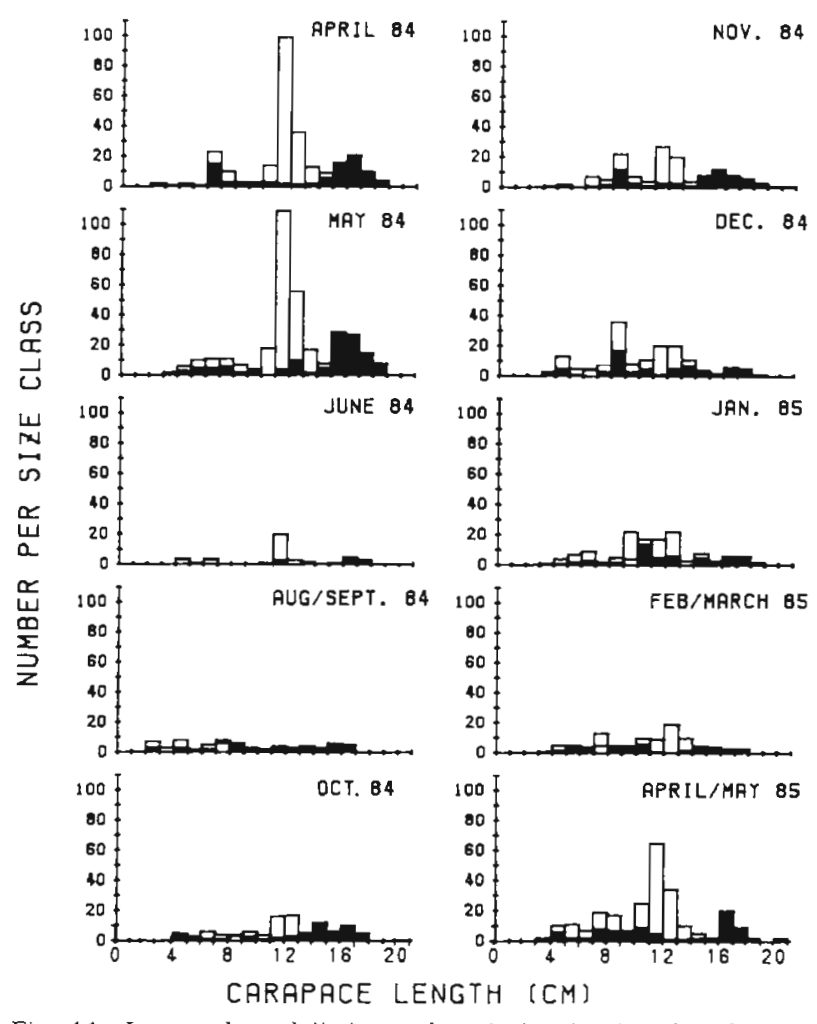

Fig. 11. Jasus edwardsij. Annual variation in size distribution at Inner Tabletop. Proportion of each size class comprised by males is shown in black

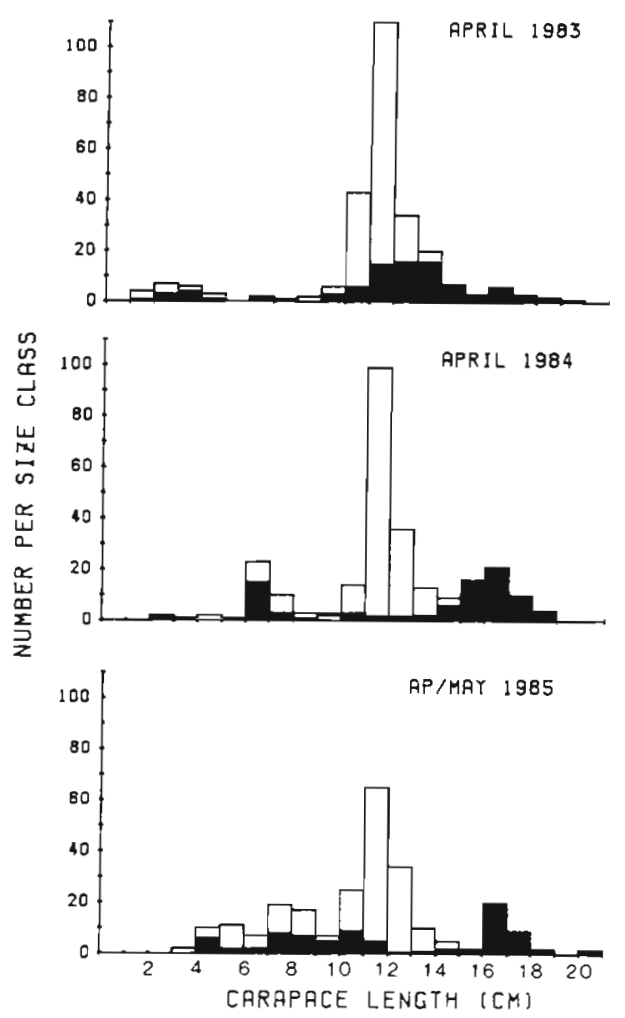

Fig. 12. Jasus edwardsii. Inter-annual variation in size distribution at Inner Tabletop Reef. Proportion of each size class comprised by males is shown in black 


\section{Inshore-offshore movements of tagged lobsters}

A total of 2345 daytime resightings of tagged spiny lobsters was made on Tabletop Reef. The majority $(85 \%)$ were resighted at Inner Tabletop as part of another study to describe daily movement (MacDiarmid et al. in press). Few lobsters were resighted at Mid Tabletop (3\%), Outer Tabletop (11\%) or Site $4(1 \%)$. The distribution of effort to detect tagged lobsters was also highest at Inner Tabletop. Of the $616 \mathrm{~h}$ spent underwater $54 \%$ were at this site. Less time was spent at Mid Tabletop (21\%), Outer Tabletop (21\%) or Site 4 $(4 \%)$.

A total of 178 inshore or offshore movements of tagged lobsters was recorded (Table 2). For females inshore movements of pre-moult individuals predominated in the autumn months (March, April and May). In contrast, during winter (June, July, August) after females had moulted, mated, and were carrying eggs, most moved offshore. In spring and summer females moved both inshore and offshore. All but 3 of the inshore movements by females in spring occurred in late September and early October immediately after their eggs hatched.

During spring and autumn tagged males moved both in and offshore (Table 2). During winter and summer offshore movements by males predominated. Offshore movements of males in winter did not carry past the reef edge at Outer Tabletop, while in summer males continued over the sandflat to reach the deep patch reefs (Site 4). Four tagged males (size range 134 to $167 \mathrm{~mm} \mathrm{CL}$ ) moved beyond the Marine Reserve boundary and over summer were caught in commercial pots set over deep reefs $(35 \mathrm{~m}) 800 \mathrm{~m}$ directly offshore of Tabletop Reef.

\section{Environmental correlation}

Variation in depth distribution of lobsters may be due to fluctuations in the physical environment (Kanciruk 1980). Correlations of mean densities of spiny lobsters at sites on Tabletop Reef with average monthly sea surface temperature, sea surge and photoperiod (climate data from Evans \& Ballantine 1983, 1985 and 1986, Augustin \& Evans 1984, and New Zealand Nautical Almanac and Tide Tables 1985, Ministry of Transport, Wellington, New Zealand) were sought for males and females separately. Of the 24 possible correlations only 2 were barely significant; one would be expected by chance alone. The density of females at Inner Tabletop was positively correlated with sea surface temperature $(r=0.4359, \mathrm{df}=20, \mathrm{p}<0.05)$ and overall densities of females on Tabletop Reef were positively correlated with changes in photoperiod $(r=0.4707$ $\mathrm{df}=19, \mathrm{p}<0.05)$.

\section{DISCUSSION}

In exploited palinurid populations it is difficult to determine if variations in apparent abundance, sex ratio and/or size distribution are due to natural cycles or fluctuations in fishing mortality, area fished, and catchability (Morgan 1974b). This study, conducted in an area closed to fishing, using methods suitable for determining small-scale distributions, shows that natural variations in the density and structure of a population of Jasus edwardsii were scale dependent. On Tabletop Reef spiny lobster population size was relatively stable over the $3 \mathrm{yr}$ study. This resulted from 2 factors. Although J. edwardsii are able to travel great

Table 2. Jasus edwardsij. Numbers of inshore and offshore movements of tagged males and females recorded each season. Data from 1983, 1984, and 1985 have been pooled. Chi-square values for number of observed and expected (0.5 total n) onshore and offshore movements are given in brackets. V Values significant at 0.05 level

\begin{tabular}{|c|c|c|c|c|c|c|c|c|c|c|}
\hline & \multicolumn{2}{|c|}{$\begin{array}{l}\text { Summer } \\
\text { Dec-Feb }\end{array}$} & \multicolumn{2}{|c|}{$\begin{array}{l}\text { Autumn } \\
\text { Mar-May }\end{array}$} & \multicolumn{2}{|c|}{$\begin{array}{l}\text { Winter } \\
\text { Jun-Aug }\end{array}$} & \multicolumn{2}{|c|}{$\begin{array}{l}\text { Spring } \\
\text { Sep-Nov }\end{array}$} & \multicolumn{2}{|c|}{ Total } \\
\hline & $\mathrm{n}$ & $\%$ & $n$ & $\%$ & $n$ & $\%$ & $\mathrm{n}$ & $\%$ & $\mathrm{n}$ & $\%$ \\
\hline \multicolumn{11}{|l|}{ Males } \\
\hline Inshore & 3 & $18 \%$ & 13 & $62 \%$ & 1 & $8 \%$ & 17 & $59 \%$ & 34 & $46 \%$ \\
\hline Offshore & 14 & $82 \%$ & 8 & $38 \%$ & 11 & $92 \%$ & 12 & $41 \%$ & 45 & $57 \%$ \\
\hline Total & 17 & $\left(7.12^{\circ}\right)$ & 21 & (1.19) & 12 & $\left(8.33^{\circ}\right)$ & 29 & $(0.86)$ & 79 & (1.53) \\
\hline \multicolumn{11}{|l|}{ Females } \\
\hline Inshore & 7 & $39 \%$ & 21 & $72 \%$ & 3 & $14 \%$ & 19 & $61 \%$ & 50 & $51 \%$ \\
\hline Offshore & 11 & $61 \%$ & 8 & $28 \%$ & 18 & $86 \%$ & 12 & $39 \%$ & 49 & $49 \%$ \\
\hline Total & 18 & $(0.89)$ & 29 & $\left(5.83^{\circ}\right)$ & 21 & $\left(10.71^{\circ}\right)$ & 31 & $(1.59)$ & 99 & $(0.01)$ \\
\hline \multicolumn{11}{|l|}{ Total } \\
\hline Inshore & 10 & $32 \%$ & 34 & $68 \%$ & 4 & $12 \%$ & 36 & $61 \%$ & 84 & $47 \%$ \\
\hline Offshore & 25 & $68 \%$ & 16 & $32 \%$ & 29 & $88 \%$ & 24 & $39 \%$ & 94 & $53 \%$ \\
\hline Total & 35 & $\left(6.43^{\circ}\right)$ & 50 & $\left(6.48^{\circ}\right)$ & 33 & $\left(18.94^{\circ}\right)$ & 59 & $(2.86)$ & 178 & $(0.56)$ \\
\hline
\end{tabular}


distances (Street 1969, McKoy 1983), at least $45 \%$ of spiny lobsters on Tabletop Reef were resident for a year or more (MacDiarmid 1987). The losses that did occur, through natural mortality and emigration, were balanced by settlement and immigration.

Within the reef, however, there were marked seasonal changes in the density of males and females at each depth which affected sex ratios and size distributions in a cyclical manner. These differences occurred over spatial scales of only $300 \mathrm{~m}$ and were maintained at night during nocturnal foraging (MacDiarmid et al. in press). Although sites at the same depth and habitat in the Marine Reserve sometimes differed in density of spiny lobsters, the sex ratio and size distribution were usually very similar at the same time of year, indicating that similar cycles occurred at places other than Tabletop Reef.

On the scale of replicate quadrats the density of spiny lobsters within a site varied markedly particularly at times of high abundance as indicated by the wide confidence limits around the estimates of mean density. Patchy spatial distribution is a feature of palinurids (Zimmer-Faust \& Spanier 1987). Seasonal changes in dispersion and gregarity of Jasus edwardsii will be described elsewhere (MacDiarmid unpubl.).

The cyclical nature of the changes in density, sex ratio and size distribution of Jasus edwardsij at each depth, and the phase lag between fluctuations in shallow and deep areas, suggest that adult males and females move up and down the reef at particular and different times of the year. This was supported by seasonal movements of tagged lobsters. However, the detection of movement depended upon the presence of tagged lobsters at each depth and upon effort at every depth to determine the identity of tagged individuals that did move. These 2 requirements were not evenly distributed on Tabletop Reef, both being highest at Inner Tabletop. The resulting bias on movement patterns is difficult to determine. The larger number of tagged spiny lobsters at Inner Tabletop, compared to any other depth, would bias the pattern towards offshore movements at all times of the year (i.e., larger numbers of tagged lobsters were available inshore to be detected later offshore than vice versa). However, the larger numbers of hours spent underwater by divers at Inner Tabletop than at any other depth would make it more likely that divers would detect the inshore movements of the few spiny lobsters that were tagged or resighted further offshore. These 2 factors may counterbalance each other. The patterns of movement detected were not affected by biases induced by tagging (MacDiarmid et al. in press).

The regular fluctuations in density, sex ratio and size distribution at each depth implied the operation of some causal factor(s). Seasonal changes in density, sex ratio and size distribution in other species of spiny lobster have been linked to variations in sea temperature (Davis 1977), dissolved oxygen levels (Newman \& Pollock 1971, Bailey et al. 1985), storm events (Mercer 1975, Herrnkind 1980) and photoperiod (Kanciruk \& Herrnkind 1973). In this study, sea surface temperature and photoperiod were weakly correlated to changes in densities of female spiny lobsters but this need not indicate a causal relationship. They may only indirectly affect density and distribution by influencing the annual timing of moulting, reproduction and feeding activities (Sastry 1983, Lipcius \& Herrnkind 1987).

In the period April-November moulting and reproductive activities appeared to be the primary factors affecting the depth distribution of Jasus edwardsii. Highest densities of females in water $<10 \mathrm{~m}$ deep coincided with their moulting period (late April-June,

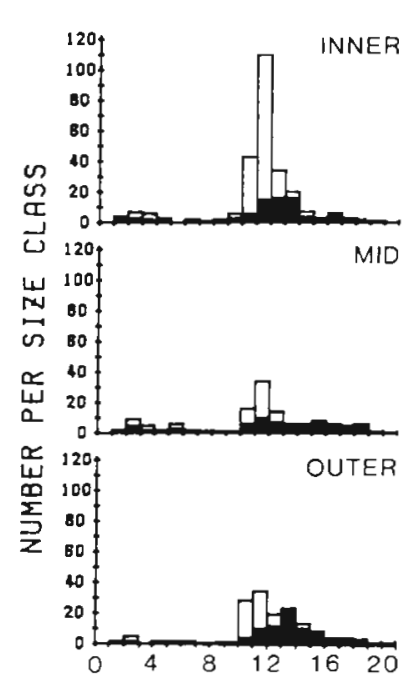

SEPTEMBER 1983

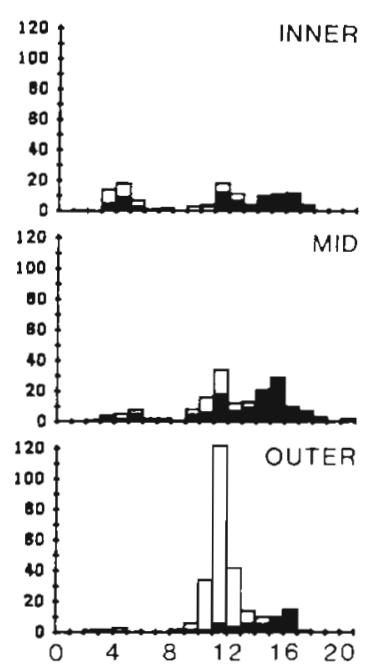

CARAPACE LENGTH (CM)
NOVEMBER 1982

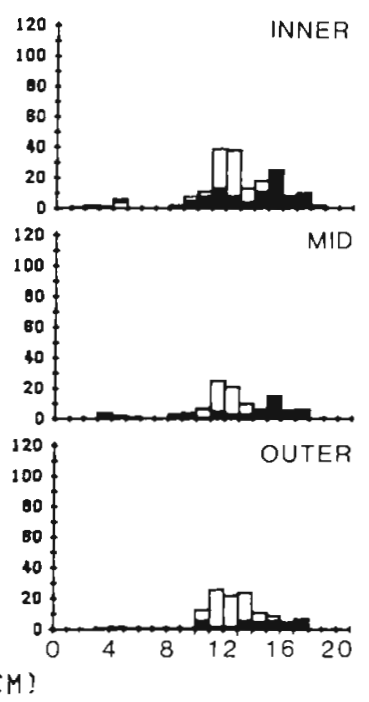

Fig. 13. Jasus edwardsii. Variation in size frequency between depths on Tabletop Reef at 3 times of year. Proportions of each size class comprised by males is shown in black 
MacDiarmid 1989b). This was not always the case for males. Data on location of fresh lobster exuvae were used to estimate that $64 \%$ of males on Tabletop Reef moulted in shallow water at Inner Tabletop (MacDiarmid 1989b). But density data from this study indicate that at times during the male moulting period (OctoberNovember) only $20 \%$ of males on Tabletop Reef were at Inner Tabletop. Tagged males moved both in and offshore at this time of year. Obviously individual males were making only temporary excursions to shallow water to moult. Why the majority of spiny lobsters moved inshore to moult is not known. It is not readily explained in terms of predator avoidance, optimal temperature or shelter availability as large predatory reef fish were most abundant in the shallows, there was no thermal stratification over the reef, and shelter was available at all depths (MacDiarmid 1989b).

Over the mating period in June (MacDiarmid 1989) the densities of both females and males were similar at all depths. However, once females had mated and were carrying eggs they moved offshore to the deep seaward part of reefs. Peak densities at these depths occurred in September towards the end of the incubation period and did not begin to drop until October when some females moved back up into the shallows once their eggs had hatched (MacDiarmid 1985, 1989b). High abundance of ovigerous females at the base of reefs have been found in other areas of New Zealand (McKoy \& Leachman 1982) and in other palinurids (Berry 1971, Hermkind 1980, Lyons et al. 1981, Gregory et al. 1982, MacFarlane \& Moore 1986). Herrnkind (1980) and McKoy \& Leachman (1982) suggested that movement to the seaward edge of reefs assures broad larval dispersal by currents. It may also reduce predation on larvae by planktivorous reef fish which, when abundant, can significantly reduce local zooplankton densities (e.g. Gaines \& Roughgarden 1987, Kingsford \& MacDiarmid 1988)

The limited extent to which most ovigerous females moved offshore in this study does not preclude them from making much longer migrations in areas where the coastal reef extends further out to sea. Jasus edwardsii occur to depths of at least $275 \mathrm{~m}$ and there is some exchange between these deep and inshore populations (Annala \& Bycroft 1984), indicating that ovigerous females might be capable of substantial movements. In other species ovigerous females may move 10 to $200 \mathrm{~km}$ to hatch their eggs (Lyons et al. 1981, Gregory et al. 1982, Moore \& MacFarlane 1984).

The influence of feeding activities upon depth distribution of Jasus edwardsii during the period April to November was probably small. Palinurids do not feed for up to $44 \mathrm{~d}$ before and $34 \mathrm{~d}$ after ecdysis or during the mating period (Dall 1975, Zoutendyk 1988, MacDiarmid pers. obs.). Reduced temperatures during winter may lessen the demand for food (Zoutendyk 1988). However, during summer (December to February) feeding activities were probably more important in determining depth distribution. This is the period of peak food consumption by male Jasus lalandii (Zoutendyk 1988) and is a period of high catch rates of $J$. edwardsii in baited traps in exploited areas adjacent to the Marine Reserve (Sanders 1986). The extended summer distribution of males into deeper water beyond Tabletop Reef to Site 4 and the seaward boundary of the Marine Reserve coincided with spiny lobsters feeding on bivalves on the extensive sand flats surrounding the deeper reefs. Only during summer were large numbers of freshly opened bivalves, mostly dog cockles Glycmeris laticostata, found around the margins of the reefs or in shelters. Night observations revealed few spiny lobsters on the deep reefs but many on the surrounding sand flats and some carrying bivalves back towards shelter. Other palinurids often forage over sand flats (Herrnkind et al. 1975, Jernakoff 1987).

Cyclical changes in the depth distribution of Jasus edwardsii found in this study, and similar cycles inferred elsewhere (Street 1969, Pollock 1979, 1982, Annala \& Bycroft 1984), suggest that in all species of the J. lalandii group (sensu George \& Kensler 1970), large, annual changes in density, sex ratio and size distribution occur with respect to depth. However, in other areas the exact timing of these annual cycles, the depth range over which they occur, and the horizontal extent of inshore-offshore movement are likely to be different from those observed in this study. This is because of latitudinal and size-dependent variations in the timing of moulting and reproduction (Street 1969, McKoy \& Esterman 1981, Lipcius 1985, MacDiarmid $1989 \mathrm{a}, \mathrm{b})$, and differences in the depth range of suitable habitats (e.g. Bailey et al. 1985) and major prey species (e.g. Newman \& Pollock 1974).

In conclusion, there are large, predictable changes in depth distribution of adult male and female Jasus edwardsii, which lead to fluctuations in sex ratio and size frequency. These fluctuations occur in the absence of a fishery and appear related to the annual timing of moulting, reproductive and feeding activities. Knowledge of such patterns is the first step of ecological research (Andrew \& Mapstone 1987) and is a prerequisite to understanding the role lobsters have in regulating prey species. It will also be a key to examining factors affecting changes in spiny lobster populations on a larger scale.

Acknowledgements. I thank all those who assisted in the field but particularly $B$. Hickey whose help during lobster tagging was invaluable. I thank B. A. Foster, G. P. Jones, R. H. Mattlin and $J$. R. Zeldis for critically reading the manuscript. This work was supported by a research grant from the N.Z. Ministry of Agriculture and Fisheries, Fisheries Research Centre. 


\section{LITERATURE CITED}

Andrew, N. L., Mapstone, B. D. (1987). Sampling and description of spatial pattern in marine ecology. Oceanogr. mar. Biol. A. Rev. 25: 39-90

Annala, J. H., Bycroft, B. L. (1984). Exploratory fishing for rock lobsters in offshore areas near Gisborne. New Zealand Ministry of Agriculture and Fisheries, Fisheries Research Division Occasional Publication No. 45: 1-10

Augustin, J., Evans, J. H. (1984). The climate in 1983: Climate $\mathrm{X}$. Unpubl. report, University of Auckland Leigh Marine Laboratory No. 17: 1-32

Bailey, G. W., Beyers, C. J., Lipschitz, S. R. (1985). Seasonal variation of oxygen deficiency in waters off southern south west Africa in 1975 and 1976 and its relation to the catchability and distribution of the Cape rock lobster Jasus lalandii. S. Afr. J. mar. Sci. 3: 197-214

Ballantine, W. J. (1987). New Zealand's course for marine reserves. New Scient. 1563: 54-55

Barkai, A., Branch, G. M. (1988). Contrasts between the benthic communities of subtidal hard substrata at Marcus and Malgas Islands: a case of alternative stable states? S. Afr. J. mar. Sci. 7: 117-137

Berry, P. F. (1971). The spiny lobsters (Palinuridae) of the east coast of southern Africa. Distribution and ecological notes. Investl Rep. oceanogr. Res. Inst. S. Afr. Ass mar. Biol. Res. 27: $1-23$

Berry, P. F., Smale, M. J. (1980). An estimate of production and consumption rates in the spiny lobster Panulirus homarus on a shallow littoral reef off the Natal coast, South Africa. Mar. Ecol. Prog. Ser. 2: 337-343

Breen, P. A., Booth, J. H. (1989). Puerulus and juvenile abundance in the rock lobster Jasus edwardsii at Stewart Island, New Zealand (Note). N.Z. Jl mar. Freshwat. Res. 23: 519-523

Brethes, J. C., Bouchard, R., Desrosiers, G. (1985). Determination of the area prospected by a baited trap from a tagging and recapture experiment with snow crabs. J. Northw. A.tl. Fish. Sci. 6: 37-42

Campbell, A., Stasko, A. B. (1985). Movements of tagged American lobsters, Homarus americanus, off south-western Nova Scotia. Can. J. Fish. Aquat. Sci. 42: 229-238

Chittleborough, R. G. (1974). Development of a tag for the western rock lobster. C.S.I.R.O. Div. Fish. Oceanogr. Rep. 56: $1-19$

Dall, W. (1975). Indices of nutritional state in the western rock lobster Panulirus longipes (Milne Edwards). II. Gastric fluid constituents. J. exp. mar. Biol. Ecol. 18: 1-18

Davis, G. E. (1977). Effects of recreational harvest on a spiny lobster, Panulirus argus population. Bull. mar. Sci. 27. 223-236

Davis, G. E., Dodrill, J. W. (1989). Recreational fishery and population dynamics of spiny lobsters, Panulirus argus in Florida Bay, Everglades National Park, 1977-1980. Bull. mar. Sci. 44: 78-88

Ennis, G. P. (1984). Small scale seasonal movements of the American lobster Homarus americanus. Trans. Am. Fish. Soc. 113: 336-338

Evans, J. H., Ballantine, W. J. (1983). The climate in 1982 : Climate VI. Unpubl report, University of Auckland Leigh Marine Laboratory No. 10: 1-30

Evans, J. H., Ballantine, W. J. (1985). The climate in 1984 Climate XI. UnpubL report, University of Auckland Leigh Marine Laboratory No. 18: 1-33

Evans, J. H., Ballantine, W. J. (1986). The climate in 1985 Climate XII. Unpubl. report, University of Auckland Leigh Marine Laboratory No. 19: 1-32
Ford, R. F. (1980). Introduction. In: Cobb, S. J., Phillips, B. F (eds.) The biology and management of rock lobsters Vol. II. Ecology and management. Academic Press, New York, p. 3-9

Ford, R. F., Phillips, B. F., Joll, L. M. (1988). Experimental manipulation of population density and its effects on growth and mortality of juvenile western rock lobsters, Panulirus cygnus George. Fish. Bull. U.S. 86: 773-787

Gaines, S. D., Roughgarden, J. (1987). Fish in offshore kelp forests affect recruitment to intertidal barnacle populations. Science 235: 479-481

George, R. W., Kensler, C. B. (1970). Recognition of marine spiny lobsters of the Jasus lalandii group (Crustacea Decapoda: Palinuridae). N.Z. Jl mar. Freshwat. Res. 4 292-311

Green, R. H. (1979). Sampling design and statistical methods for environmental biologists. John Wiley \& Sons, New York

Gregory, D. R., Labisky, R. F., Combs, C. L. (1982). Reproductive dynamics of the spiny lobster Panulirus argus in South Florida. Trans. Am. Fish. Soc. 111: 575-584

Herrnkind, W. F. (1980). Spiny lobsters: patterns of movement. In: Cobb, J. S., Phillips, B. F. (eds.) The biology and management of lobsters. Vol. I. Physiology and behaviour. Academic Press, New York, p. 349-407

Herrnkind, W. F., VanDerwalker, J., Barr, L. (1975). Population, dynamics, ecology and behaviour of spiny lobster, Panulirus argus of St John, U.S. Virgin Islands: habitation and pattern of movements. Results of the Tektite Program, Vol 2. Sci. Bull. nat. Hist. Mus. Los Angeles Cty 20: 31-45

Heydorn, A. E. F. (1969). The rock lobster of the South African west coast Jasus lalandii (H. Milne-Edwards). 2. Population studies, behaviour, reproduction, moulting, growth, and migration. Investl Rep. Div. Sea Fish. S. Afr. 71: 1-52

Jernakoff, P. (1987). Foraging patterns of juvenile western rock lobster Panulirus cygnus Ceorge. J. exp. mar. Biol. Ecol. 113: 125-144

Jernakoff, P., Phillips, B. F., Maller, R. A. (1987). A quantitative study of the foraging distances of the western rock lobster Panulirus cygnus George. J. exp. mar. Biol. Ecol. 113: 9-21

Jernakoff, P., Phillips, B. F. (1988). Effect of a baited trap on the foraging movements of juvenile western rock lobsters, Panulirus cygnus George. Aust. J. mar. Freshwat. Res. 39: 185-192

Kanciruk, P. (1980). Ecology of juvenile and adult Palinuridae (spiny lobsters). In: Cobb, J. S., Phillips, B. F. (eds.) The biology and management of lobsters. Vol. II. Ecology and management. Academic Press, New York, p. 59-96

Kanciruk, P., Herrnkind, W. F. (1973). Preliminary investigations of the daily and seasonal locomotor activity rhythms of the spiny lobster, Panulirus argus. Mar. Behav. Physiol. 1: $351-359$

Kanciruk, P., Herrnkind, W. F. (1976). Autumnal reproduction in Panulirus argus at Bimini, Bahamas. Bull. mar. Sci. 26: $417-432$

Karnofsky, E. B., Atema, J., Elgin, R. H. (1989). Natural dynamics of population structure and habitat use of the lobster Homarus americanus in a shallow cove. Biol. Bull. mar biol. Lab., Woods Hole 176: 247-256

Kingsford, M. J., MacDiarmid, A. B. (1988). Interrelations between plaktivorous reef fish and zooplankton in temperate waters. Mar Ecol. Prog. Ser. 48: 103-117

Lipcius, R. N. (1985). Size dependent reproduction and moulting in spiny lobsters and other long lived decapods. In: Wenner, A. (ed.) Crustacean issues. Vol. 3. Factors in adult growth. Balkema Press, Rotterdam, p. 129-148 
Lipcius, R. N, Hermkind, W. F. (1987). Control and coordination of reproduction in the spiny lobster Panulirus argus. Mar. Biol. 96: 207-214

Lyons, W. G., Barber, D. G., Foster, S. N., Kennedy, F. S. Jr, Milano, G. R. (1981). The spiny lobster, Panulirus argus, in the middle and upper Florida Keys: population structure, seasonal dynamics and reproduction. Fla mar Res. Publs 38: $1-38$

MacDiarmid, A. B. (1985). Sunrise release of larvae from the Palinurid rock lobster Jasus edwardsii. Mar. Ecol. Prog. Ser. 21: 313-315

MacDiarmid, A. B. (1987). The ecology of Jasus edwardsii (Hutton) (Crustacea: Palinuridae). Ph.D. thesis, University of Auckland

MacDiarmid, A. B. (1989a). Size at onset of maturity and size dependent reproductive output of female and male spiny lobsters Jasus edwardsii (Hutton) (Decapoda Palinuridae) in northern New Zealand. J. exp. mar. Biol. Ecol. 127: 229-243

MacDiarmid, A. B. (1989b). Moulting and reproduction of the spiny lobster Jasus edwardsii (Decapoda Palinuridae) in northern New Zealand. Mar. Biol. 103: 303-310

MacDiarmid, A. B., Hickey, B., Maller, R. A. (in press). Daily movement patterns of the spiny lobster Jasus edwardsii (Hutton) on a shallow reef in northern New Zealand. J. exp. mar. Biol. Ecol.

MacFarlane, J. W., Moore, R. (1986). Reproduction of the ornate rock lobster Panulirus ornatus (Fabricius), in Papua New Guinea. Aust. J. mar. Freshwat. Res. 37: 55-65

McCormick, M. I., Choat, J. H. (1987). Estimating total abundance of a large temperate reef fish using visual strip transects. Mar. Biol. 96: 469-478

McKoy, J. L. (1983). Movements of rock lobsters, Jasus edwardsii (Decapoda: Palinuridae) tagged near Stewart Island, New Zealand. N.Z. Jl mar. Freshwat. Res. 17: 357-366

McKoy, J. L., Esterman, D. B. (1981). Growth of rock lobsters (Jasus edwardsii) in the Gisborne region. New Zealand. N.Z. Jl mar. Freshwat. Res. 15: 121-136

McKoy, J. L., Leachman, A. (1982). Aggregations of ovigerous female rock lobsters Jasus edwardsii (Decapoda: Palinuridae). N.Z. Jl mar. Freshwat. Res. 16: 141-146

Mercer, J. P. (1975). Spiny lobster Palinurus vulgaris (Latreille) on the West Coast of Ireland. Proc. Challenger Soc. 4: 124-125

Moore, R., MacFarlane, J. W. (1984). Migration of the ornate rock lobster, Palinurus ornatus (Fabricius), in Papua New Guinea. Aust. J. mar. Freshwat. Res. 35: 197-212

Morgan, G. R. (1974a). Aspects of the population dynamics of the western rock lobster, Palinurus cygnus, George. 1. Estimation of population density. Aust. J1 mar. Freshwat. Res. 25: 235-248

Morgan, G. R. (1974b). Aspects of the population dynamics of the western rock lobster, Palinurus cygnus, George. II.

This article was presented by G. C. Harding, Dartmouth, N.S., Canada
Seasonal changes in the catchability coefficient. Aust. Jl mar. Freshwat. Res. 25: 249-259

Newman, G. G., Pollock, D. E. (1971). Biology and migration of rock lobster Jasus lalandii and their effect on availability at Elands Bay, South Africa. Invest] Rep. Div. Sea Fish. S. Afr. 94:1-24

Newman, G. G., Pollock, D. E. (1974). Biological cycles, maturity and availability of rock lobster Jasus lalandii on two South African fishing grounds. Investl Rep. Div. Sea Fish. S. Afr 107: 1-16

Paterson, N. F. (1968). The anatomy of the Cape rock lobster, Jasus lalandii (H. Milne Edwards). Ann. S. Afr Mus. 51: $1-232$

Peacock, N. A. (1974). A study of the spiny rock lobster fishery of Antigua and Barbuda. Proc. Gulf Caribb. Fish Inst. 26: $117-130$

Phillips, B. F. (1990). Estimating the density and mortality of juvenile western rock lobsters (Panulirus cygnus) in nursery reefs. Can. J. Fish. Aquat. Sci. 47: 1330-1338

Pollock, D. E. (1973). Growth of juvenile rock lobster Jasus lalandii. Investl Rep. Div. Sea Fish. S. Afr. 106: 1-16

Pollock, D. E. (1979). Predator-prey relationships between the rock lobster Jasus lalandii and the mussel Aulacomya ater at Robbin Island on the Cape west coast of South Africa. Mar. Biol. 52: 347-356

Pollock, D. E. (1982). The fishery for and population dynamics of west coast rock lobster related to the environment in the Lambert's Bay and Port Nolloth areas. Investl Rep. Div. Sea Fish. S. Afr. 124: 1-53

Pringle, D. I. (1984). Efficiency estimates for various quadrat sizes used in benthic sampling. Can. J. Fish. Aquat. Sci. 41: 1485-1489

Sanders, B. M. (1986). The 1985 New Zealand rock lobster landings. Fish. Res. Div. Occas. Pub.: Data Ser., N.Z. Dep Ag. Fish. 29: 1-31

Sastry, A. N. (1983). Ecological aspects of reproduction. In: Bliss, D. E. (ed.). The biology of Crustacea. Vol. 8. Environmental adaptations. Academic Press, New York. p. $179-270$

Schmitt, R. J. (1982). Consequences of dissimilar defenses against predation in a subtidal marine community. Ecology 63: 1588-1601

Smith, G. B., van Nierop, M. (1986). Abundance and potential yield of spiny lobster (Panulirus argus) on Little and Great Bahama Banks. Bull. mar. Sci. 39: 646-656

Street, R. J. (1969). The New Zealand crayfish Jasus edwardsii (Hutton). Fisheries Technical Report, N.Z. Marine Department 30: 1-24

Zimmer-Faust, R. K., Spanier, E. (1987). Gregariousness and sociality in spiny lobsters: implications for den habitation. J. exp. mar. Biol. Ecol. 105: 57-71

Zoutendyk, P. (1988). Consumption rates of captive lobster Jasus lalandii. S. Afr. J. mar. Sci. 6: 267-271

Manuscript first received: May 10, 1989

Revised version accepted: December 6, 1990 